Original research article

Food Quality and Functionality Section

\title{
Effect of Boiling on Colour, Contents of Betalains and Total Phenolics and on Antioxidant Activity of Colourful Powder Derived from Six Different Beetroot (Beta vulgaris L. var. conditiva) Cultivars
}

\author{
Jan Bárta ${ }^{1}$, Veronika Bártová ${ }^{1 *}$ ๑ , Tereza Šindelková ${ }^{1}$, Markéta Jarošová ${ }^{1}$, Zuzana Linhartováa ${ }^{\circledR}$, \\ Jan Mráz $z^{3}$, Jan Bedrníček ${ }^{2}$, Pavel Smetana $^{2}$,Eva Samkováa ${ }^{\circledR}$, Ivana Laknerová ${ }^{4}$ \\ ${ }^{1}$ Faculty of Agriculture, Department of Plant Production, University of South Bohemia, \\ Na Sádkách 1780, 370 05, České Budějovice, Czech Republic \\ ${ }^{2}$ Faculty of Agriculture, Department of Food Biotechnology and Agricultural Products Quality, University of South Bohemia, \\ Na Sádkách 1780, 370 05, České Budějovice, Czech Republic \\ ${ }^{3}$ Faculty of Fisheries and Protection of Waters, South Bohemian Research Center of Aquaculture and Biodiversity \\ of Hydrocenoses, Institute of Aquaculture and Protection of Waters, University of South Bohemia, \\ Na Sádkách 1780, 370 05, České Budějovice, Czech Republic \\ ${ }^{4}$ Food Research Institute, Radiová 1285/7, 102 00, Prague, Czech Republic
}

Key words: beetroot, Beta vulgaris L. conditiva, beetroot meal, cultivar, boiling, betalain pigments, antioxidant activity

\begin{abstract}
Powders prepared from freeze-dried roots of six beetroot (Beta vulgaris L.) cultivars with red (cv. D'Egypte, Karkulka, Betina, Alexis), yellow (cv. Burpee's Golden) or red-white (cv. Chioggia) colour of root flesh were evaluated before and after boiling treatment $\left(20 \mathrm{~min}, 100^{\circ} \mathrm{C}\right)$. Water and fat holding capacity (WHC and FHC), colour, contents of betalains and total phenolics (TPCs), and antioxidant activity were all significantly affected by cultivar as well as powder thermal treatment. WHC increased after boiling of the powder and varied between cultivars from $2.14 \mathrm{~g} / \mathrm{g}$ (cv. D'Egypte) to $2.59 \mathrm{~g} / \mathrm{g}$ (cv. Chioggia). The highest FHC of $1.22 \mathrm{~g} / \mathrm{g}$ was observed in cv. Betina. Colour stability was optimal in the cultivars with red root flesh; with their lightness decrease between 6 and 10\%. This corresponded with betalain content that was the highest in red cv. Betina; for which the values before and after boiling were 18.10 and $15.04 \mathrm{mg} / \mathrm{g} \mathrm{DM}$, respectively. Cultivar Betina significantly exceeded the other cultivars also in TPCs and antioxidant activity. The TPCs values of this cultivar were 3.73 and $3.32 \mathrm{mg}$ gallic acid equivalents/g DM in the unboiled and boiled variant, respectively. Antioxidant activity of Betina powder before and after boiling was 11.13 and $11.69 \mathrm{mg}$ ascorbic acid equivalents/g DM, respectively. The results indicated the significance of beetroot cultivar selection for thermal processing. Beetroots with red flesh significantly exceeded yellow and red-white cultivars in all the evaluated characteristics.
\end{abstract}

\section{INTRODUCTION}

Beetroot (Beta vulgaris L. conditiva) is a traditional and important vegetable all over the world that is usually consumed in traditional western cuisine [Nistor et al., 2017; Sawicki et al., 2016; Vasconcellos et al., 2016]. It contains over $80 \%$ of water, while such components as saccharides, dietary fiber, nitrogenous substances, and ash prevail in its dry matter (DM) [Vasconcellos et al., 2016; Wruss et al., 2015]. However, consumer interest in beetroot has arisen due to the content of minor compounds implicated in numerous health benefits. These compounds include particularly betalains, phenolic acids, flavonoids, and ascorbic acid, which may increase the total antioxidant capacity of beetroot [Chhikara et al., 2019; Ravichandran et al., 2012; Vasconcellos et al., 2016; Wruss et al., 2015].

Attractiveness of beetroot for consumers is mainly due to the colour of root flesh, which as a cultivar-specific trait,

\footnotetext{
* Corresponding Author: vbartova@zf.jcu.cz (V. Bártová)
}

offers different shades of red and red-violet. Beetroot cultivars with yellow and red-white (alternate red and white rings in cross-section) root flesh colour are well-known (Plant Variety Database - European Commission). Root flesh colour is derived from betalains, being water-soluble nitrogenous pigments having a core structure known as betalamic acid [Ravichandran et al., 2013]. Average content of betalains in beetroot is $0.1 \mathrm{~g} / 100 \mathrm{~g}$ of fresh root matter but it can be up to $2 \mathrm{~g} / \mathrm{kg}$ of fresh matter in some cultivars [Velíšek, 2014]. Betalains consist of two main groups, the red-violet betacyanins (major pigment is betanin) and the yellow betaxanthins (major pigment is vulgaxanthin) [Celli \& Brooks, 2017; Sawicki et al., 2016]. They are free radical scavengers and prevent oxygen-induced and free radical-mediated oxidation of biological molecules [Sawicki \& Wiczkowski, 2018]. However, betalains exhibit also anticarcinogenic [Chhikara et al., 2019; Gengatharan et al., 2015] and antimicrobial activities [Celli \& Brooks, 2017]. Stability of betalain pigments is influenced by betalain structure and composition, $\mathrm{pH}$ value, water activity, oxygen, light, metal and antioxidant 
presence, and temperature that represents the most important factor [Güneşer 2016].

Beetroot can be consumed as fresh vegetable, beetroot juice, after heat cooking or as a component of, e.g., food products [Ranawana et al., 2016]. Powder derived from red beetroot or beetroot pomace [Porto Dalla Costa et al., 2017] can be applied in bakery [Kohajdová et al., 2018], or meat products [Sucu et al., 2018]. Functional properties, including water and fat holding (absorption) capacity, gelling ability, emulsifying activity and others are important for these types of beetroot application. Changes in these functional characteristics occurring during heat treatment are crucial for the use of beetroot in food applications. The attractiveness of beetroot powder is due to its red colour, pigment content, and total antioxidant activity, all of which can be influenced by heat treatment [Nistor et al., 2017; Ravichandran et al., 2013; Sawicki \& Wiczkowski, 2018].

The aim of this study was to evaluate the impact of boiling on colour, antioxidant activity, and betalain pigment and phenolic contents in different colourful powders prepared from several beetroot cultivars.

\section{MATERIAL AND METHODS}

\section{Plant material and beetroot powder processing}

Plants of six beetroot (Beta vulgaris var. conditiva) varieties (Table 1) were cultivated in south-bohemian region (GPS N 49 39' 56", E $14^{\circ} 88^{\prime}$ '68') under organic crop management in 2018. No mineral fertilizers, pesticides or other chemical preparations were applied during the growing season. Roots of ten average beet plants were used to prepare a freeze-dried powder. Roots were thoroughly washed, dried, and weighed. Afterwards, they were cut into 2-mm thin slices, frozen at $-20^{\circ} \mathrm{C}$, and subsequently freeze-dried using a freeze-drier (ALPHA 1-4 LSD, Martin Christ, Germany) under a temperature of $-50^{\circ} \mathrm{C}$, pressure of $\leq 0.420 \mathrm{mbar}$, and time period of $72 \mathrm{~h}$. Freeze-dried samples were grinded using a planetary mono mill (Pulverisette 6, Fritsch, Germany) under 450 rpm for $2 \mathrm{~min}$ to obtain a beetroot powder.

Colour, functional properties, and antioxidant characteristics were analysed in the beetroot powders before and after powder heat treatment. Two g of the prepared beetroot powders were mixed with $20 \mathrm{~mL}$ of deionised water and carefully shaken. These powder mixtures were placed in a water bath with a temperature of $100^{\circ} \mathrm{C}$ for $20 \mathrm{~min}$ (time was measured after reaching the temperature of $100^{\circ} \mathrm{C}$ in sample interior). After centrifugation ( $15 \mathrm{~min}, 3,600 \times g$, and $20^{\circ} \mathrm{C}$ ) and supernatant removal, the beetroot powders were cooled, freeze-dried to constant weight, and pulverised by using a planetary mill (Pulverisette 6) under $450 \mathrm{rpm}$ for $2 \mathrm{~min}$ to obtain a boiled variant of the beetroot powder.

\section{Water solubility and water holding capacity}

Water solubility (S) and water holding capacity (WHC) of unprocessed beetroot powders were analysed by weighing $300 \mathrm{mg}$ of powder and mixing with $5 \mathrm{~mL}$ of deionised water. The tubes with the mixture were allowed to stand at room temperature for 30 min under continuous shaking. Samples were centrifuged $\left(15 \mathrm{~min}, 3,600 \times g\right.$, and $\left.20^{\circ} \mathrm{C}\right)$. The superna- tant was discarded and tubes with pellet were weighed, freeze-dried $\left(-50^{\circ} \mathrm{C},<0.420 \mathrm{mbar}, 48 \mathrm{~h}\right)$, and afterwards weighed again. Solubility and water holding capacity were computed from the obtained weight data according to the following formulas (Equations 1-3).

$\mathrm{S}(\%)=100 *\left(\mathrm{~m}_{\mathrm{s}}-\mathrm{m}_{\mathrm{lp}}\right) / \mathrm{m}_{\mathrm{s}}$

$\mathrm{WHC}_{\text {powder }}(\mathrm{g} / \mathrm{g})=\left(\mathrm{m}_{\mathrm{wp}}-\mathrm{m}_{\mathrm{lp}}\right) / \mathrm{m}_{\mathrm{s}}$

$\mathrm{WHC}_{\text {non-soluble part }}(\mathrm{g} / \mathrm{g})=\left(\mathrm{m}_{\mathrm{wp}}-\mathrm{m}_{\mathrm{lp}}\right) / \mathrm{m}_{\mathrm{lp}}$

where: $\mathrm{S}$ - a water solubility of beetroot powder DM (\%), $\mathrm{m}_{\mathrm{s}}-$ weight of the sample $(\mathrm{g}), \mathrm{m}_{\mathrm{lp}}$ - weight of the freeze-dried pellet $(\mathrm{g}), \mathrm{WHC}_{\text {powder }}$ - water holding capacity of beetroot powder ( $g$ of water per $g$ of powder DM), $m_{w p}$ - weight of the wet pellet $(\mathrm{g})$, and $\mathrm{WHC}_{\text {non-soluble part }}$ - water holding capacity of DM of beetroot powder non-soluble part ( $\mathrm{g}$ of water per $\mathrm{g}$ of non-soluble part DM).

Water solubility and water holding capacity of the heat-treated beetroot powder were determined by the same analytical procedure as described for the unprocessed powders and computed with Equation 1 and Equation 4, respectively.

$$
\mathrm{WHC}_{\text {non-soluble part after boiling }}(\mathrm{g} / \mathrm{g})=\left(\mathrm{m}_{\text {wpab }}-\mathrm{m}_{\mathrm{lpab}}\right) / \mathrm{m}_{\mathrm{lpab}}
$$

where: $\mathrm{WHC}_{\text {non-soluble part after boiling }}$ - water holding capacity of non-soluble part of powder after boiling ( $g$ of water per $g$ of non-soluble part DM), $\mathrm{m}_{\text {wpab }}$ - weight of the wet pellet after boiling $(\mathrm{g})$, and $\mathrm{m}_{\mathrm{lpab}}$ - weight of the freeze-dried pellet after boiling $(\mathrm{g})$.

\section{Fat holding capacity}

Fat holding capacity (FHC) was determined analogously as WHC with the following differences: $5 \mathrm{~mL}$ of rapeseed oil were used instead of $5 \mathrm{~mL}$ of water. Supernatant (oil phase) was thoroughly discarded after centrifugation and tubes with pellet were weighed. The obtained weight of fatted pellet data allowed computing the FHC values (Eq. 5).

$\mathrm{FHC}(\mathrm{g} / \mathrm{g})=\left(\mathrm{m}_{\mathrm{fs}}-\mathrm{m}_{\mathrm{s}}\right) / \mathrm{m}_{\mathrm{s}}$

where: FHC - fat holding capacity ( $\mathrm{g}$ of oil per $\mathrm{g}$ of powder $\mathrm{DM}), \mathrm{m}_{\mathrm{fs}}-$ weight of the fatted pellet $(\mathrm{g})$, and $\mathrm{m}_{\mathrm{s}}-$ weight of the sample $(\mathrm{g})$.

\section{Colour analysis}

Colour of beetroot powder was measured for all evaluated cultivars before and after boiling, using a colorimeter ColorEye XTH (X-Rite, Grand Rapids, MI, USA) which is based on CIE (Commission Internationale de l'Eclairrage) system and provides $\mathrm{L}^{*} \mathrm{a}^{*} \mathrm{~b}^{*}$ parameters ( $\mathrm{L}^{*}$ lightness, $0 \%$ - black, $100 \%$ - white; $a^{*}$ red - green; $b^{*}$ yellow - blue).

\section{Betalain content}

The betalain content was determined spectrophotometrically. Beetroot powder $(100 \mathrm{mg})$ was extracted with $1 \mathrm{~mL}$ of $50 \%$ ethanol for $30 \mathrm{~min}$. Supernatants were collected after centrifugation $\left(20^{\circ} \mathrm{C}, 3,600 \times g, 15 \mathrm{~min}\right)$. The extraction pro- 
cedure was repeated twice and the final total extract volume was $3 \mathrm{~mL}$. The absorbance of the obtained and diluted (1:50) extracts was read (BioMate 5 spectrophotometer, ThermoFisher Scientific, Waltham, MA, USA) at $\lambda=540 \mathrm{~nm}$ for betacyanins (BCs) and at $\lambda=480 \mathrm{~nm}$ for betaxanthins (BXs). The absorbance was used to calculate the betalain, betacyanin, and betaxanthin contents for each sample (Eq. 6).

$\mathrm{BC}$ or $\mathrm{BX}(\mathrm{mg} / \mathrm{g})=\mathrm{A}_{540 / 480} \times \mathrm{DF} \times \mathrm{MW} \times \mathrm{V} / \varepsilon \times \mathrm{L} \times \mathrm{Wd}$

where: $\mathrm{BC}$ or $\mathrm{BX}$ - content of betacyanins (BCs) or betaxanthins (BXs) (mg/g), $\mathrm{A}_{540 / 480}$ - absorbance at absorption maximum for BCs $(\lambda=540 \mathrm{~nm})$ or BXs $(\lambda=480 \mathrm{~nm})$, DF dilution factor, MW - molecular weight: $550 \mathrm{~g} / \mathrm{mol}$ for BCs and $308 \mathrm{~g} / \mathrm{mol}$ for BXs, V - volume of sample solution (mL), $\varepsilon$ - the molar extinction coefficient $60,0001 /(\mathrm{M} \times \mathrm{cm})$ for $\mathrm{BCs}$ and $48,0001 /(\mathrm{M} \times \mathrm{cm})$ for BXs, $\mathrm{L}$ - path length of the cuvette $(1 \mathrm{~cm})$, and $\mathrm{Wd}-$ weight of the dried sample $(\mathrm{g})$.

\section{Total phenolic content}

The total phenolic content (TPC) was determined spectrophotometrically using the Folin-Ciocalteau's reagent after previous extraction of phenolics from freeze-dried matter using $80 \%$ ethanol with a solid-to-solvent ratio of 1:20 $(w / v)$. The extraction was performed for $24 \mathrm{~h}$ under room temperature, and the mixtures were then centrifuged at $3,600 \times g$ for $10 \mathrm{~min}$, filtered, and subsequently refrigerated at $4^{\circ} \mathrm{C}$ until analysed. The reaction mixture contained $20 \mu \mathrm{L}$ of the beetroot extract, $1980 \mu \mathrm{L}$ of distilled water, $100 \mu \mathrm{L}$ of Folin-Ciocalteau's reagent, and $300 \mu \mathrm{L}$ of $20 \%(w / v)$ sodium carbonate. Absorbance was read at $\lambda=734 \mathrm{~nm}$ (BioMate 5 spectrophotometer) after $2 \mathrm{~h}$. Gallic acid was used as a standard and the results obtained were expressed as mg of gallic acid equivalent (GAE) per g of sample DM [Hamouz et al., 2006].

\section{Antioxidant activity}

The beetroot powder extracts for determination of the antioxidant activity (AOA) were prepared as described for TPC determination. Antioxidant activity was determined using ABTS and DPPH methods according to Šulc et al. [2007] with modifications. Ascorbic acid was used as the standard for both of the methods and results were expressed as mg of ascorbic acid equivalent (AAE) per g of sample DM.

(2,2'-Azino-bis(3-ethylbenzothiazoline-6-sulfonic acid) diammonium salt (ABTS) was dissolved in the amount of $54.9 \mathrm{mg}$ in $20 \mathrm{~mL}$ of a $5 \mathrm{mM}$ phosphate buffer ( $\mathrm{pH} 7.4$ ), and BTS radical cations were activated by $1 \mathrm{~g} \mathrm{MnO}_{2}$. The filtered solution (PTFE $0.25 \mu \mathrm{m}$ ) was diluted in a $5 \mathrm{mM}$ phosphate buffer to the absorbance of $0.800 \pm 0.01$ at $\lambda=734 \mathrm{~nm}$. Absorbance of the reaction mixture $\left(1 \mathrm{~mL} \mathrm{ABTS}{ }^{*+}\right.$ solution and $100 \mu \mathrm{L}$ of beetroot extract) was measured at $\lambda=734 \mathrm{~nm}$.

2,2-Diphenyl-1-picrylhydrazyl (DPPH) radical in the amount of $0.025 \mathrm{~g}$ was dissolved in $100 \mathrm{~mL}$ of methanol to obtain a stock solution. The reaction mixture was prepared by mixing $975 \mu \mathrm{L}$ of $10 \%(v / v) \mathrm{DPPH}^{\bullet}$ stock solution and $25 \mu \mathrm{L}$ of the beetroot extract. Absorbance of the reaction mixture was measured at $\lambda=515 \mathrm{~nm}$ after 30 -min incubation under room temperature.

\section{Statistical analysis}

Data obtained were statistically examined by the one-way (water and fat holding capacity) or two-way (content of betalain pigments, TPCs, antioxidant activity) analysis of variance (ANOVA), and significant differences were determined using the Fisher LSD test at a significance level of $p<0.05$. Relations among selected parameters were tested using the correlation analysis. Statistical evaluation was performed with the STATISTICA software, version 12 (StatSoft Inc., USA). Three independent replicates were performed for each evaluated parameter.

\section{RESULTS AND DISCUSSION}

\section{Functional properties of beetroot powder}

Our study was carried out with the group of six beetroot cultivars with different colour of root flesh. The list of the analysed cultivars with their basic characteristics (root flesh colour, weight, and DM content) are shown in Table 1. Average weight of the roots ranged between 202 (cv. Alexis) and $404 \mathrm{~g}$ (Burpee's golden), while differences between cultivars in DM content were found to be in a narrow range from 13.3 (cv. Burpee's golden) to $15.0 \mathrm{~g} / 100 \mathrm{~g}$ (cv. D'Egypte). Similar DM of beetroots were also found by Szopińska \& Gaweda [2013] and Kazimierczak et al. [2014].

High WHC values were determined in powders from cultivars Chioggia and Betina (Table 2), i.e. 1.88 and $1.81 \mathrm{~g} / \mathrm{g}$ powder, respectively. However, WHC of these cultivars did not differ significantly from WHC of cultivars Burpee's golden and Karkulka. In contrast, the lowest WHC was determined in the powder from beetroot of cv. D'Egypte. The content

TABLE 1. List of beetroot cultivars and description of root characteristics.

\begin{tabular}{lcc|c|c|c}
\hline Beetroot cultivar & Country of origin & Root shape & Root flesh colour & $\begin{array}{c}\text { Average root weight } \\
(\mathrm{g})\end{array}$ & $\begin{array}{c}\text { Dry matter content } \\
(\mathrm{g} / 100 \mathrm{~g})\end{array}$ \\
\hline Alexis & $\mathrm{CZ}$ & cylindrical & deep red & 202 & 13.40 \\
Betina & $\mathrm{CZ}$ & spherical & deep red & 269 & 13.52 \\
Burpee's Golden & UK & spherical & yellow (golden) & 404 & 13.29 \\
Chioggia & IT & spherical & rings of red and white & 379 & 14.91 \\
D'Egypte & PL (CZ, FR, ES, IT) & flattened & deep red & 323 & 15.03 \\
Karkulka & CZ & cylindrical & deep red & 390 & 14.69 \\
\hline
\end{tabular}


TABLE 2. Functional properties of beetroot powders.

\begin{tabular}{|c|c|c|c|c|c|c|}
\hline \multirow{2}{*}{ Beetroot cultivars } & \multirow{2}{*}{$\begin{array}{l}\text { Water solubility } \\
\qquad(\%)\end{array}$} & \multicolumn{2}{|c|}{ Water holding capacity (g/g) } & \multicolumn{2}{|c|}{ Water holding capacity after boiling $(\mathrm{g} / \mathrm{g})$} & \multirow{2}{*}{$\begin{array}{c}\text { Fat holding } \\
\text { capacity }(\mathrm{g} / \mathrm{g})\end{array}$} \\
\hline & & Powder & Non-soluble part & Powder & Non-soluble part & \\
\hline Alexis & $68.53 \pm 2.65^{\mathrm{a}}$ & $1.65 \pm 0.05^{\mathrm{bc}}$ & $4.71 \pm 0.09^{\mathrm{c}}$ & $2.35 \pm 0.10^{\mathrm{bc}}$ & $6.21 \pm 0.07^{c}$ & $1.09 \pm 0.04^{b}$ \\
\hline Betina & $65.45 \pm 0.95^{\mathrm{ab}}$ & $1.81 \pm 0.01^{\mathrm{ab}}$ & $5.24 \pm 0.12^{\mathrm{a}}$ & $2.59 \pm 0.05^{\mathrm{a}}$ & $6.91 \pm 0.12^{\mathrm{a}}$ & $1.22 \pm 0.06^{\mathrm{a}}$ \\
\hline Burpee's Golden & $66.75 \pm 2.30^{\mathrm{ab}}$ & $1.69 \pm 0.05^{\mathrm{ab}}$ & $5.07 \pm 0.06^{\mathrm{ab}}$ & $2.23 \pm 0.08^{\mathrm{c}}$ & $6.41 \pm 0.06^{\mathrm{bc}}$ & $1.15 \pm 0.03^{\mathrm{ab}}$ \\
\hline Chioggia & $64.48 \pm 2.36^{\mathrm{b}}$ & $1.88 \pm 0.13^{\mathrm{a}}$ & $5.28 \pm 0.28^{\mathrm{a}}$ & $2.56 \pm 0.18^{\mathrm{ab}}$ & $6.60 \pm 0.15^{\mathrm{b}}$ & $1.13 \pm 0.05^{\mathrm{b}}$ \\
\hline D'Egypte & $68.27 \pm 1.54^{\mathrm{a}}$ & $1.53 \pm 0.19^{c}$ & $4.78 \pm 0.32^{\mathrm{bc}}$ & $2.14 \pm 0.07^{\mathrm{c}}$ & $6.22 \pm 0.16^{\mathrm{c}}$ & $1.14 \pm 0.05^{\mathrm{ab}}$ \\
\hline Karkulka & $65.76 \pm 1.90^{\mathrm{ab}}$ & $1.72 \pm 0.06^{\mathrm{ab}}$ & $5.02 \pm 0.10^{\mathrm{abc}}$ & $2.29 \pm 0.18^{c}$ & $6.24 \pm 0.20^{c}$ & $1.14 \pm 0.07^{\mathrm{ab}}$ \\
\hline
\end{tabular}

Means with different subscript letters for the water and fat holding capacity indicate significant differences according to the one-way ANOVA (factor cultivar), Fisher LSD test $(p<0.05)$. Results are shown for the dry matter of powder/non-soluble part of powder.

of water-soluble components varied from 64.48 to $68.53 \%$, depending on cultivar. Increasing the proportion of water non-soluble components resulted in WHC increase before and after powder boiling. The boiling process increased WHC of the powders made of all of cultivars tested. After boiling, the highest WHC values were determined for the powders made of cultivars Betina and and Chioggia and reached 2.59 and $2.56 \mathrm{~g} / \mathrm{g}$ powder, respectively. Differences in WHC after boiling between these two cultivars were not statistically significant $(p>0.05)$.

Similarly, high FHC value was determined in the powder of cv. Betina with a low water solubility. However, the determined FHC values did not differ significantly from these assayed in powders from beetroots of cultivars Burpee's golden, D'Egypte, and Karkulka. The FHC of Betina powder reached $1.22 \mathrm{~g} / \mathrm{g}$; the variability between cultivars was from 1.09 (Alexis) to $1.22 \mathrm{~g} / \mathrm{g}$ (Betina). The WHC and FHC values of wheat powder have been usually determined at 1.1 and $2.5 \mathrm{~g} / \mathrm{g}$, respectively [Menon et al., 2015]. Data obtained in our study show beetroot powder to be a material with high values of WHC and FHC; thus suitable as a component of powder mixtures usable in products expected to absorb water and/or fat. Porto Dalla Costa et al. [2017] have presented high WHC (mean $10.14 \mathrm{~g}$ water/g powder) and FHC (mean $3.3 \mathrm{~g} / \mathrm{g}$ powder) for beetroot powder prepared from waste pomace. Such a high WHC was probably due to the high contents of insoluble fiber and protein in this type of beetroot material. In agreement with this assumption, we found the highest content of total dietary fiber in powder from cv. Chioggia $(11.6 \%$ of DM) (not published data of authors). This explains the highest value of WHC and the lowest value of water solubility found in the powder from this beetroot cultivar. The two components, fibers and proteins, are considered to be predominant in the powder ability to retain oil and water [Menon et al., 2015; Porto Dalla Costa et al., 2017], and responsible for increasing viscosity, preventing syneresis, and modifying product's texture [Porto Dalla Costa et al., 2017].

In this context, beetroot powder is a promising additive in food systems that can replace, at least partly, wheat and soybean powders as functional components in products expected to hold up water and/or oils [Kohajdová et al., 2018] or in reduced-energy products [Chau et al., 2004].

\section{Colour of beetroot powder}

The colour of beetroot powder differed significantly among the cultivars $(p<0.05)$ and the colour parameters were significantly influenced by the boiling process (Figure 1). Four tested cultivars had different shades of deep red colour, roots of one cultivar had red-white strips and another one yellow (golden) colour (Table 1). The L* parameter values of beetroot powder of the non-boiled samples were (Figure 1) in the range from 46.86 (cv. Alexis) to 84.87 (cv. Burpee's Golden). The values of $b^{*}$ colour parameter ranged from 0.40 (cv. Karkulka) to 47.50 (cv. Burpee's golden). Deep red colour was observed in beetroot powder from cultivars D'Egypte, Karkulka, Betina, and Alexis. The beetroot powder made of all cultivars tested had a more intensive colour before than after boiling Colour parameters of beetroot samples changed after boiling and the $\mathrm{L}^{*}$ parameter values were from 40.16 (cv. Betina) to 57.78 (cv. Burpee's Golden). The greatest decreases of lightness caused by boiling were found in the powders prepared from Burpee's Golden (decrease by 27\%) and Chioggia (decrease by 18.6\%) roots. The decrease of $\mathrm{L}^{*}$ value noted for the root powder from the redo-coloured cultivar was only between $6 \%$ and $10 \%$. Beetroot characteristic coloration and colour stability during thermal treatment depends on the content and stability of highly active pigments, especially betalains [Guldiken et al., 2016] and carotenoids [Ninfali \& Donato, 2013]. Betalains (betacyanins and betaxanthins) may be degraded during heat processing mainly by isomerisation, hydrolysis, decarboxylation, and dehydrogenation to brown and yellow constituents [Bach et al., 2015; Herbach et al., 2004]. The main beetroot betaxanthin, i.e. vulgaxanthin I, is more degradable by heat than the main betacyaninsm such as betanin and isolbetanin [Herbach et al., 2004].

The effect of temperature on the visually-assessed colour of beetroot powder was reported by Bach et al. [2015] and Chandran et al. [2014]. Chandran et al. [2014] observed that temperature had no significant effect on $\mathrm{L}^{*}$ value, but caused modification in $a^{*}$ and $b^{*}$ values. With an increase of temperature, $a^{*}$ value decreased with a corresponding increase in $b^{*}$ values. Similar trends were observed in our experiment with the exception of cv. Burpee's Golden with yellow colour of the original beetroot powder. However, data pre- 


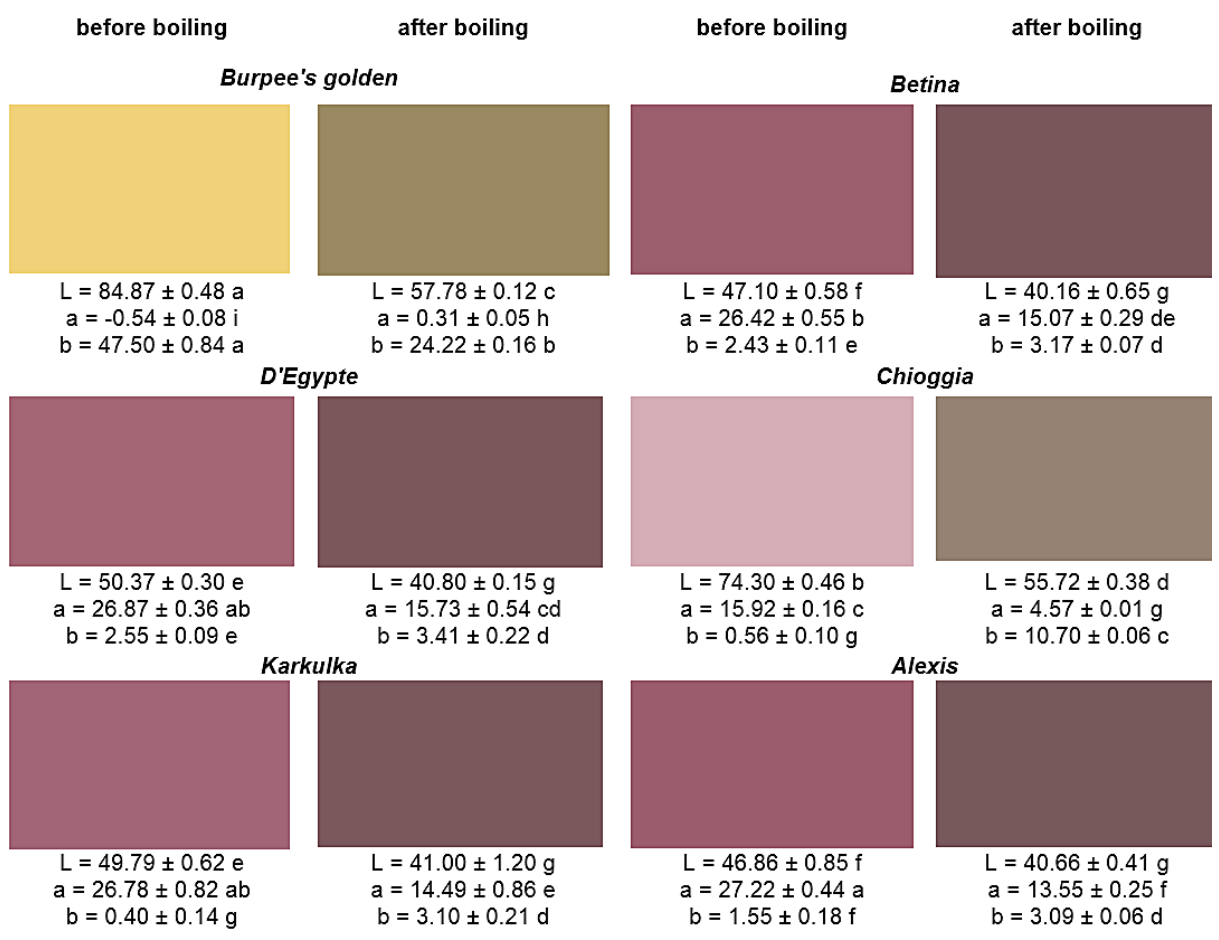

FIGURE 1. Colour of the powder from different beetroot cultivars before and after boiling treatment.

Means with different subscript letters for each colour parameter indicate significant differences according to the two-way ANOVA (evaluated factors: cultivar and sample treatment), Fisher LSD test $(p<0.05)$.

sented by Chandran et al. [2014] were based on the analysis of one unknown deep purple cultivar. In turn, Bach et al. [2015] evaluated the effect of beetroot cultivar and culinary preparation on colour changes. The decrease of colour intensity was not so extensive in red beetroot cultivars (Taunus, Rosket a Pablo) as in the red-white beetroot cultivar Chioggia. In cv. Burpee's Golden, the authors did not observe such a great decrease of colour intensity as we found in our experiment.

\section{Contents of betacyanins, betaxanthin, and betalains}

As presented above, betalain content, composition, and thermal stability affect beetroot powder colour before and after boiling. Table 3 collates contents of betacyanins and betaxanthins, the two categories of betalains, in dependence on beetroot cultivar and thermal treatment of beetroot powder. Before boiling, the content of betalains (BLs) in powder of red beetroot cultivars ranged from 10.92 (cv. D'Egypte) to 18.10 (cv. Betina) $\mathrm{mg} / \mathrm{g}$ DM. Powders of yellow beetroot cultivar Burpee's Golden and red-white cultivar Chioggia contained only 2.07 and $1.38 \mathrm{mg} / \mathrm{g}$ DM of BLs, respectively. A relative decrease in betalain content caused by boiling the beetroot powder ranged from $9 \%$ to $29 \%$, depending on cultivar.

The content of red-violet pigments - betacyanins (BCs), in the tested powders followed the similar trend as it was found for BLs. The BCs content in beetroot powders of red root cultivars ranged from 6.63 (cv. D'Egypte) to $11.14 \mathrm{mg} / \mathrm{g}$ DM (cv. Betina). Red-white cultivar Chioggia and yellow root cultivar Burpee's Golden contained 0.90 and $0.54 \mathrm{mg} / \mathrm{g}$ $\mathrm{DM}$ of $\mathrm{BCs}$, respectively. Boiling treatment led to a decrease in $\mathrm{BCs}$ content in the range from 3 to $28 \%$.
The content of yellow-orange pigments - betaxanthins (BXs), was higher in the powder from the red root cultivars (interval within cultivars was found between 4.29 and $6.95 \mathrm{mg} / \mathrm{g}$ $\mathrm{DM}$ ) than in the powder from the yellow cv. Burpee's Golden $(1.53 \mathrm{mg} / \mathrm{g} \mathrm{DM})$ and red-white cv. Chioggia $(0.48 \mathrm{mg} / \mathrm{g} \mathrm{DM})$. The lowest BCs/BXs ratio was demonstrated for the yellow cultivar in both types of powder before and after boiling. The highest ratio indicated the strong supremacy of betacyanins in roots of this cultivar. The BXs level was also reduced by the boiling treatment, the reduction varied between $8 \%$ and $36 \%$. The content of BXs in the boiled powder samples varied between 0.44 (cv. Chioggia) and $5.31 \mathrm{mg} / \mathrm{g} \mathrm{DM}$ (cv. Betina). Data of BCs/BXs indicate the lower thermal stability of BXs in comparison with BCs.

The BLs, BCs, and BXs contents found in our experiment were generally higher than literature data. The total content of BLs was mostly reported within the broad range of 4-17 mg/g DM, depending on the cultivar [Sawicki et al., 2016; Slatnar et al., 2015]. Sawicki et al. [2016] described, in a set of 13 red beetroot cultivars, the content of total BLs in the range from 10.26 to $17.15 \mathrm{mg} / \mathrm{g} \mathrm{DM}$, the contents of BCs and their derivatives from 7.18 to $13.50 \mathrm{mg} / \mathrm{g}$ $\mathrm{DM}$, and BXs content within the range of $2.71-4.25 \mathrm{mg} / \mathrm{g}$ DM. The lowest content of betalains was found in red beetroot varieties from Finland (4.43-9.60 mg/g DM), as well as in those grown in the United States $(0.65-0.80 \mathrm{mg} / \mathrm{g} \mathrm{FM})$ [Lee et al., 2014]. Unfortunately, betalains are highly sensitive to light, heat, and oxygen [Kowalski et al., 2014; Nistor et al., 2017]. The colour and flavour of dried red beetroots are considered to be the most important quality attributes affecting their acceptability by consumers [Nistor et al., 2017; Sorour 
TABLE 3. Content of betalain pigments in beetroot powders before and after boiling treatment.

\begin{tabular}{l|c|c|c|c|c|c|c|c}
\hline \multirow{2}{*}{ Beetroot cultivars } & \multicolumn{2}{|c|}{ BC content $(\mathrm{mg} / \mathrm{g}$ DM) } & \multicolumn{2}{c|}{ BX content $(\mathrm{mg} / \mathrm{g} \mathrm{DM})$} & \multicolumn{2}{c|}{ Betalains $(\mathrm{mg} / \mathrm{g}$ DM) } & \multicolumn{2}{c}{ BCs/BXs ratio } \\
\cline { 2 - 9 } & $\begin{array}{c}\text { Before } \\
\text { boiling }\end{array}$ & $\begin{array}{c}\text { After } \\
\text { boiling }\end{array}$ & $\begin{array}{c}\text { Before } \\
\text { boiling }\end{array}$ & $\begin{array}{c}\text { After } \\
\text { boiling }\end{array}$ & $\begin{array}{c}\text { Before } \\
\text { boiling }\end{array}$ & $\begin{array}{c}\text { After } \\
\text { boiling }\end{array}$ & $\begin{array}{c}\text { Before } \\
\text { boiling }\end{array}$ & $\begin{array}{c}\text { After } \\
\text { boiling }\end{array}$ \\
\hline Alexis & $10.63 \pm 0.39^{\mathrm{a}}$ & $8.69 \pm 0.07^{\mathrm{c}}$ & $6.15 \pm 0.23^{\mathrm{b}}$ & $4.55 \pm 0.03^{\mathrm{d}}$ & $16.78 \pm 0.62^{\mathrm{b}}$ & $13.23 \pm 0.10^{\mathrm{d}}$ & 1.73 & 1.91 \\
Betina & $11.14 \pm 0.32^{\mathrm{a}}$ & $9.73 \pm 0.51^{\mathrm{b}}$ & $6.95 \pm 0.21^{\mathrm{a}}$ & $5.31 \pm 0.28^{\mathrm{c}}$ & $18.10 \pm 0.52^{\mathrm{a}}$ & $15.04 \pm 0.79^{\mathrm{c}}$ & 1.60 & 1.83 \\
Burpee's Golden & $0.54 \pm 0.01^{\mathrm{g}}$ & $0.50 \pm 0.50^{\mathrm{g}}$ & $1.53 \pm 0.05^{\mathrm{f}}$ & $0.98 \pm 0.12^{\mathrm{g}}$ & $2.07 \pm 0.05^{\mathrm{i}}$ & $1.48 \pm 0.12^{\mathrm{i}}$ & 0.35 & 0.51 \\
Chioggia & $0.90 \pm 0.02^{\mathrm{g}}$ & $0.72 \pm 0.72^{\mathrm{g}}$ & $0.48 \pm 0.01^{\mathrm{h}}$ & $0.44 \pm 0.05^{\mathrm{h}}$ & $1.38 \pm 0.02^{\mathrm{i}}$ & $1.16 \pm 0.13^{\mathrm{i}}$ & 1.88 & 1.64 \\
D'Egypte & $6.63 \pm 0.44^{\mathrm{e}}$ & $6.42 \pm 0.62^{\mathrm{e}}$ & $4.29 \pm 0.22^{\mathrm{d}}$ & $3.51 \pm 0.34^{\mathrm{e}}$ & $10.92 \pm 0.63^{\mathrm{f}}$ & $9.93 \pm 0.96^{\mathrm{g}}$ & 1.55 & 1.83 \\
Karkulka & $7.72 \pm 0.17^{\mathrm{d}}$ & $5.58 \pm 0.66^{\mathrm{f}}$ & $4.45 \pm 0.10^{\mathrm{d}}$ & $3.17 \pm 0.39^{\mathrm{e}}$ & $12.17 \pm 0.27^{\mathrm{e}}$ & $8.75 \pm 1.05^{\mathrm{h}}$ & 1.73 & 1.76 \\
\hline
\end{tabular}

Means with different subscript letters for contents of betacyanins (BC), betaxanthins (BX), and betalains indicate significant differences according to the two-way ANOVA (evaluated factors: cultivar and sample treatment), Fisher LSD test $(p<0.05)$; DM - dry matter.

TABLE 4. Total phenolic content and antioxidant activity of beetroot powder before and after boiling treatment.

\begin{tabular}{l|c|c|c|c|c|c}
\hline \multirow{2}{*}{ Beetroot cultivar } & \multicolumn{2}{|c|}{$\begin{array}{c}\text { TPC } \\
\text { (mg GAE/g DM) }\end{array}$} & \multicolumn{2}{c}{ ABTS method } & \multicolumn{3}{c}{ DPPH method } \\
\cline { 2 - 7 } & Before boiling & After boiling & Before boiling & After boiling & Before boiling & After boiling \\
\cline { 2 - 7 } & $3.25 \pm 0.21^{\mathrm{cb}}$ & $3.49 \pm 0.13^{\mathrm{ab}}$ & $10.58 \pm 2.64^{\mathrm{a}}$ & $10.7 \pm 0.69^{\mathrm{a}}$ & $6.77 \pm 1.30^{\mathrm{def}}$ & $16.90 \pm 0.31^{\mathrm{ab}}$ \\
Alexis & $3.73 \pm 0.43^{\mathrm{a}}$ & $3.32 \pm 0.21^{\mathrm{cb}}$ & $11.13 \pm 1.19^{\mathrm{a}}$ & $11.69 \pm 0.09^{\mathrm{a}}$ & $8.68 \pm 0.90^{\mathrm{d}}$ & $17.59 \pm 0.29^{\mathrm{a}}$ \\
Betina & $1.47 \pm 0.14^{\mathrm{f}}$ & $0.93 \pm 0.05^{\mathrm{g}}$ & $5.65 \pm 0.23^{\mathrm{c}}$ & $2.75 \pm 0.07^{\mathrm{d}}$ & $4.90 \pm 1.13^{\mathrm{fg}}$ & $13.45 \pm 0.47^{\mathrm{c}}$ \\
Burpee's Golden & $1.39 \pm 0.14^{\mathrm{f}}$ & $0.64 \pm 0.11^{\mathrm{g}}$ & $5.73 \pm 0.23^{\mathrm{c}}$ & $2.03 \pm 0.03^{\mathrm{d}}$ & $4.29 \pm 0.85^{\mathrm{g}}$ & $8.36 \pm 2.77^{\mathrm{d}}$ \\
Chioggia & $2.58 \pm 0.93^{\mathrm{d}}$ & $2.22 \pm 0.10^{\mathrm{e}}$ & $7.67 \pm 0.63^{\mathrm{b}}$ & $7.71 \pm 0.24^{\mathrm{b}}$ & $6.11 \pm 1.06^{\mathrm{efg}}$ & $16.44 \pm 0.65^{\mathrm{ab}}$ \\
D'Egypte & $3.09 \pm 0.29^{\mathrm{c}}$ & $2.46 \pm 0.18^{\mathrm{ed}}$ & $8.47 \pm 0.66^{\mathrm{b}}$ & $7.88 \pm 0.18^{\mathrm{b}}$ & $7.96 \pm 0.52^{\mathrm{de}}$ & $15.22 \pm 1.25^{\mathrm{bc}}$ \\
Karkulka & & & & & &
\end{tabular}

Means with different subscript letters for total phenolic content (TPC) and antioxidant activity indicate significant differences according to the two-way ANOVA (evaluated factors: cultivar and sample treatment), Fisher LSD test ( $p<0.05)$; GAE - gallic acid equivalent; AAE - ascorbic acid equivalent.

et al., 2014]. However, the effect of cultivar on the betalain pigments and colour stability has not been described widely. Herbach et al. [2004] described novel yellow neobetanin structures and two orange-red betanin degradation products in thermally-treated $\left(85^{\circ} \mathrm{C}\right)$ red beet juice explaining the yellow-orange shift of thermally-treated red beet powder. Nistor et al. [2017] similarly found a decreasing level of betacyanins and betaxanthins with increasing drying temperatures in beetroot material of cv. Cylindria and also confirmed betalains heat sensitivity.

\section{Total phenolic content and antioxidant activity}

Antioxidant activity was evaluated by the ability of beetroot powder extracts to scavenge $\mathrm{ABTS}^{\cdot+}$ and $\mathrm{DPPH}^{\bullet}$ and was expressed as the equivalent of ascorbic acid. The extracts of all the cultivars demonstrated a strong potential to scavenge both radicals (Table 4). These results indicated that DPPH radicals could be strongly scavenged by degradation products released in beetroot powder during boiling (substances modification, fragmentation, etc.). This conclusion was confirmed by high correlation coefficients determined using DPPH and betalains characteristics in the boiled variant (Table 5). Both, ABTS ${ }^{\cdot+}$ and $\mathrm{DPPH}^{*}$ are suitable for evaluating the antioxidant activ- ity in individual items of fruit, vegetable and beverages; however, the DPPH method was presented as more suitable for the determination of the antioxidant activity of hydrophobic compounds [Kedare \& Singh, 2011]. The results indicated that the shift of hydrophobicity of beetroot components after thermal degradation probably resulted in increased solubility of degradation products and their enhanced reactivity with DPPH radicals. Sawicki \& Wiczkowski [2018] did not found a significant decrease of the antioxidant activity in red beet samples after boiling when the ABTS method was employed, however, if they used the DPPH method, the level of antioxidant activity was significantly lower. Nevertheless, the study of Sawicki \& Wiczkowski [2018] was made with only one cultivar (Czerwona Kula), while our results indicate a significant effect of cultivar on betalain content, stability, and antioxidant activity. According to data presented by Sawicki \& Wiczkowski [2018], boiling and fermentation of beetroot material increased the content of betanidin (aglycon of betanin), that showed activity in both aqueous and lipid bilayers [Slimen et al., 2017]. This fact could be responsible for the observed increase in the antioxidant activity of the boiled beetroot samples determined with the DPPH method. 
TABLE 5. Correlation coefficients between betalain content or TPC and antioxidant activity of beetroot powders before and after boiling treatment.

\begin{tabular}{l|l|c}
\hline & $\begin{array}{c}\text { Before } \\
\text { boiling }\end{array}$ & $\begin{array}{c}\text { After } \\
\text { boiling }\end{array}$ \\
\hline BC content vs. AOA ABTS method & $0.869^{* * * *}$ & $0.986^{* * * *}$ \\
BC content vs. AOA DPPH method & $0.794^{* * * *}$ & $0.802^{* * * *}$ \\
BX content vs. AOA ABTS method & $0.864^{* * * *}$ & $0.987^{* * *}$ \\
BX content vs. AOA DPPH method & $0.806^{* * * *}$ & $0.841^{* * * *}$ \\
BL content vs. AOA ABTS method & $0.871^{* * *}$ & $0.988^{* * *}$ \\
BL content vs. AOA DPPH method & $0.801^{* * * *}$ & $0.816^{* * * *}$ \\
TPC $v s$. AOA ABTS method & $0.812^{* * * *}$ & $0.982^{* * * *}$ \\
TPC $v s$. AOA DPPH method & $0.831^{* * * *}$ & $0.818^{* * *}$ \\
\hline
\end{tabular}

**** correlation is significant at $p<0.001$; BC - betacyanins; BX - betaxanthins; BL - betalains; TPC - total phenolic content; AOA - antioxidant activity.

The antioxidant activity determined with $\mathrm{ABTS}^{\cdot+}$ and $\mathrm{DPPH}^{\bullet}$ before boiling varied between cultivars from 5.65 (cv. Burpee's Golden) to $11.13 \mathrm{mg} \mathrm{AAE} / \mathrm{g}$ DM (cv. Betina) and from 4.29 (cv. Chioggiea) to $8.68 \mathrm{mg}$ AAE/g DM (cv. Betina), respectively. In turn, after boiling, the cultivar variability of antiradical activity against $\mathrm{ABTS}^{\cdot+}$ and $\mathrm{DPPH}^{\cdot}$ was between 2.03 (cv. Chioggia) and $11.69 \mathrm{mg} \mathrm{AAE} / \mathrm{g}$ DM (cv. Betina) and between 8.36 (cv. Chioggia) and $17.59 \mathrm{mg}$ $\mathrm{AAE} / \mathrm{g}$ DM (Betina), respectively. The lowest values of the antioxidant activity were observed for the yellow and red-white cultivars Burpee's Golden and Chioggia in all evaluated variants. This indicates the significant effect of betalain content on the total antioxidant activity of both raw beetroot powders and beetroot products after thermal treatment. The highest content of betalains was determined in cv. Betina (Table 3). This cultivar had the highest antioxidant activity in both the treatment variants of the experiment. In general, the antioxidant activity of beetroot products is mostly defined as the same or the higher for thermally-processed variants in comparison with the original samples by most of the other authors [Gokhale \& Lele, 2011; Ravichandran et al., 2012, 2013]. On the contrary, Vasconcellos et al. [2016] detected with the HPLC method about $10 \%$ reduction in the antioxidant activity of the samples of boiled red beetroot as compared with the freeze-dried ones. In the study of Gokhale \& Lele [2011], the increased antioxidant activity found after beetroot thermal treatment was ascribed to a higher extractability of betaxanthin and total phenolic compounds. This conclusion was not confirmed in our study. The increase in the antioxidant activity found with the DPPH method is rather caused by degradation products because no increase was observed in BLs and TPCs after boiling. Our results concerning the significant effect of the cultivar on components exhibiting the antioxidant activity confirm data of Sawicki et al. [2016] who observed a similarly broad range of antioxidant activities with both ABTS and DPPH methods for the extracts of 13 red beetroot cultivars. These authors also observed a positive correlation between the antioxidant activity determined with ABTS and DPPH methods and total betalain and betacyanin content, which corresponds with our results presented in Table 5 . The correlations between the antioxidant activity and contents of BCs, BXs, BLs, and TPCs were statistically significant and very similar in all of the comparisons. The highest correlation coefficients were found between antioxidant compound contents and results determined with the ABTS method for beetroot powders after boiling. Close correlations were also found between the content of total phenolics and antioxidant activity determined with ABTS and DPPH methods. Phenolic compounds belong to important beetroot antioxidant components [Chhikara et al., 2019; Guldiken et al., 2016], concentrated mainly in the peel and the crown [Kujala et al., 2002]. In our study, TPCs ranged from 2.58 to $3.73 \mathrm{mg} \mathrm{GAE} / \mathrm{g} \mathrm{DM}$ and below $1.5 \mathrm{mg} \mathrm{GAE} / \mathrm{g}$ $\mathrm{DM}$ in the powder from red root cultivars and in the powder prepared from roots with yellow and red-white colour of root flesh, respectively. The highest content was found in the cultivar Betina, while the lowest in the red-white cultivars Chioggia and Burpee's Golden. This corresponded again with the content of betalains and total antioxidant activity of beetroot powder. The TPCs was significantly lower $(p<0.05)$ after boiling in all the cultivars except for cultivar Alexis. The most intensive decrease of TPC was observed in cultivars with non-red colour of root flesh. Similarly, Guldiken et al. [2016] reported TPC values of 2.55 and $2.38 \mathrm{mg}$ GAE/g FM for raw and boiled beetroot variants, respectively. However, the analyses were given for only one cultivar and on fresh weight basis. On the contrary, Vasconcellos et al. [2016] found TPC at 0.75 and $2.79 \mathrm{mg}$ GAE/g DM for freeze-dried slices of red beetroot and for the boiled variant $\left(100^{\circ} \mathrm{C}, 40 \mathrm{~min}\right)$, respectively. In generally, the content of total phenolics of the vegetables is significantly affected by cooking style. Results obtained by other authors [Naveena et al., 2016; Wen et al., 2010] indicated that phenolic compounds were sensitive to heat treatment, but Wen et al. [2010] and Raikos et al. [2018] reported that different types of the cooking process differently affected various vegetables and some combinations of vegetable species/cultivars and heat processing increased their phenolic contents while others decreased them. This phenomenon could be explained by direct interactions between phenolics and some food components or food matrix such as fibre, fat, proteins or carbohydrates, affecting their phenolic content and bioaccessibility [Şengül et al., 2013].

\section{CONCLUSIONS}

The obtained data indicated a significant effect of cultivar on betalain content of beetroot powders that varied for boiled and raw variant from 1.38 to 18.10 and from 1.16 to $15.04 \mathrm{mg} / \mathrm{g} \mathrm{DM}$, respectively. Interestingly, the content of betaxanthins was significantly lower in the powders from the redwhite cultivar Chioggia and yellow cultivar Burpee's Golden compared to the powders from the red-coloured beetroot cultivars. The thermal treatment of beetroot powder resulted in a decrease of both betacyanin and betaxanthin contents, but also total phenolic content and antioxidant activity (except for the antioxidant activity of cv. Alexis) when assessed 
with the ABTS method. Interestingly, the use of the DPPH method resulted in a higher antioxidant activity determined in the boiled variant of beetroot powder in comparison with the non-boiled one. This indicates higher sensitivity of DPPH radical to degradation products exhibiting the antioxidant activity. Degradation of beetroot pigments during boiling treatment resulted in the shift of beetroot powder colour that was obvious especially for the yellow cultivar Burpee's Golden and red-white cultivar Chioggia. Beetroot powder before boiling was more intensive in all the evaluated cultivars. A decrease in $\mathrm{L}^{*}$ parameter (lightness) was lower for cultivars Betina and Alexis. Especially the cultivar Betina with a high antioxidant activity, total phenolic and betalain contents, but also water and fat absorption and colour stability was found promising for thermal processing. The obtained data confirmed the importance of beetroot cultivar not only for their chemical composition but also for their suitability to thermal processing and subsequent use.

\section{RESEARCH FUNDING}

The present work was supported by the Grant Agency of the University of South Bohemia in České Budějovice, project GAJU 027/2019/Z and by the Ministry of Agriculture of the Czech Republic, project NAZV QJ1610324. Jan Mráz and Zuzana Linhartová were financially supported by the Ministry of Education, Youth and Sports of the Czech Republic - project CENAKVA (LM2018099), CENAKVA Center Development (CZ.1.05/2.1.00/19.0380), and Biodiversity (CZ.02.1.01/0.0/0.0/16_025/0007370).

\section{CONFLICT OF INTEREST}

Authors declare no conflict of interest.

\section{ORCID IDs}

J. Bárta http://orcid.org/0000-0002-6830-2369;

V. Bártová http://orcid.org/0000-0003-2865-6792; M. Jarošová http://orcid.org/0000-0002-6846-3779;

Z. Linhartová http://orcid.org/0000-0001-8246-6020;

J. Mráz http://orcid.org/0000-0003-3545-1269;

J. Bedrníček http://orcid.org/0000-0003-0584-3923;

E. Samková https://orcid.org/0000-0002-9246-4456;

I. Laknerová http://orcid.org/0000-0001-7929-1127.

\section{REFERENCES}

1. Bach, V., Mikkelsen, L., Kidmose, U., Edelenbos, M. (2015). Culinary preparation of beetroot (Beta vulgaris L.): The impact on sensory quality and appropriateness. Journal of the Science of Food and Agriculture, 95, 1852-1859.

https://doi.org/10.1002/jsfa.6886

2. Belhadj Slimen, I., Najar, T., Abderrabba, M. (2017). Chemical and antioxidant properties of betalains. Journal of Agricultural and Food Chemistry, 65(4), 675-689.

https://doi.org/10.1021/acs.jafc.6b04208

3. Celli, G.B., Brooks, M.S.-L. (2017). Impact of extraction and processing conditions on betalains and comparison of prop- erties with anthocyanins - A current review. Food Research International, 100, 501-509.

https://doi.org/10.1016/j.foodres.2016.08.034

4. Chandran, J., Nisha, P., Singhal, R.S., Pandit, A.B. (2014). Degradation of colour in beetroot (Beta vulgaris L.): a kinetics study. Journal of Food Science and Technology, 51, 2678-2684.

https://doi.org/10.1007/s13197-012-0741-9

5. Chau, C., Chen, C., Lee, M. (2004). Comparison of the characteristics, functional properties, and in vitro hypoglycemic effects of various carrot insoluble fiber-rich fractions. $L W T-$ Food Science and Technology, 37, 155-160.

https://doi.org/10.1016/j.Iwt.2003.08.001

6. Chhikara, N., Kushwaha, K., Sharma, P., Gat, Y., Panghal, A. (2019). Bioactive compounds of beetroot and utilization in food processing industry: A critical review. Food Chemistry, 272, 192-200.

https://doi.org/10.1016/j.foodchem.2018.08.022

7. Gengatharan, A., Dykes, G.A., Choo, W.S. (2015). Betalains: Natural plant pigment with potential application in functional foods. LWT - Food Science and Technology, 64, 645-649.

https://doi.org/10.1016/j.Iwt.2015.06.052

8. Gokhale, S.V., Lele, S.S. (2011). Dehydration of red beet root (Beta vulgaris) by hot air drying: process optimization and mathematical modelling. Food Science and Biotechnology, 20(4), 955-964.

https://doi.org/10.1007/s10068-011-0132-4

9. Guldiken, B., Toydemir, G., Memis, K.N., Okur, S., Boyacioglu, D., Capanoglu, E. (2016). Home-processed red beetroot (Beta vulgaris L.) products: changes in antioxidant properties and bioaccessibility. International Journal of Molecular Sciences, 17, art. no. 858 .

https://doi.org/10.3390/ijms17060858

10. Güneşer, O. (2016). Pigment and color stability of beetroot betalains in cow milk during thermal treatment. Food Chemistry, 196, 220-227.

https://doi.org/10.1016/j.foodchem.2015.09.033

11. Hamouz, K., Lachman, J., Dvorak, P., Juzl, M., Pivec, V. (2006). The effect of site conditions, variety and fertilization on the content of polyphenols in potato tubers. Plant Soil and Environment, $52,407-412$.

https://doi.org/10.17221/3459-PSE

12. Herbach, K.M., Stintzing, F.C., Carle, R. (2004). Impact of thermal treatment on color and pigment pattern of red beet (Beta vulgaris L.) preparation. Food and Chemical Toxicology, 69, 491-498. https://doi.org/10.1111/j.1365-2621.2004.tb10994.x

13. Kazimierczak, R., Hallmann, E., Lipowski, J., Drela, N., Kowalik, A., Püssa, T., Matt, D., Luik, A., Gozdowski, D., Rembiałkowska, E. (2014). Beetroot (Beta vulgaris L.) and naturally fermented beetroot juices from organic and conventional production: Metabolomics, antioxidant levels and anticancer activity. Journal of the Science of Food and Agriculture, 94(13), 2618-2629. https://doi.org/10.1002/jsfa.6722

14. Kedare, S.B., Singh, R.P. (2011). Genesis and development of DPPH method of antioxidant assay. Journal of Food Science and Technology, 48, 412-422.

https://doi.org/10.1007/s13197-011-0251-1

15. Kohajdová, Z., Karovičová, J., Kuchtová, V., Lauková, M. (2018). Utilisation of beetroot powder for bakery applications. Chemical Papers, 72, 1507-1515. 
https://doi.org/10.1007/s11696-018-0392-z

16. Kowalski, S.J., Szadzinska, J. (2014). Kinetic and quality aspect of beetroots dried in non-stationary conditions. Drying Technology, 32, 1310-1318.

https://doi.org/10.1080/07373937.2014.915555

17. Kujala, T.S., Vienola, M.S., Klika, K.D., Lopocen, J.M., Pihlaja, K. (2002). Betalain and phenolic compositions of four beetroot (Beta vulgaris) cultivars. European Food Research and Technology, 214(6), 505-510.

https://doi.org/10.1007/s00217-001-0478-6

18. Lee E.J., An, D., Nguyen, C.T., Patil, B.S., Kim, J., Yoo, K.S. (2014). Betalain and betaine coposition of greenhouse- or field-produced beetroot (Beta vulgaris L.) and inhibition of HepG2 cell proliferation. Journal of Agricultural and Food Chemistry, 62(6), 1324-1331. https://doi.org/10.1021/jf404648u

19. Menon, L., Majundar, S.D., Ravi, U. (2015). Development and analysis of composite flour bread. Journal of Food Science and Technology, 52, 4156-4165.

https://doi.org/10.1007/s13197-014-1466-8

20. Naveena, N., Vishnuvardhana, R., Bhaskarachary, K. (2016). Effect of boiling and juicing on the content of polyphenols, in vitro bioaccessibility and antioxidant activity of commonly consumed vegetables and fruits. The Indian Journal of Nutrition and Dietetics, 53(4), art. no. 365.

https://doi.org/10.21048/ijnd.2016.53.4.8396

21. Ninfali, P., Donato, A. (2013). Nutritional and functional potential of Beta vulgaris cicla and rubra. Fitoterapia, 89, 188-199. https://doi.org/10.1016/j.fitote.2013.06.004

22. Nistor, O-V., Seremet Ceclu, L., Andronoiu, D.G. Rudi, L., Botez, E. (2017). Influence of different drying methods on the physicochemical properties of red beetroot (Beta vulgaris L. var. Cylindra). Food Chemistry, 236, 59-67.

https://doi.org/10.1016/j.foodchem.2017.04.129

23. Porto Dalla Costa, A., Hermes, V.S., de Oliveira Rios, Flôres, S.H. (2017). Minimally processed beetroot waste as an alternative source to obtain functional ingredients. Journal of Food Science and Technology, 54(7), 2050-2058.

https://doi.org/10.1007/s13197-017-2642-4

24. Raikos, V., McDonagh, A., Ranawana, V., Duthie, G. (2016). Processed beetroot (Beta vulgaris L.) as a natural antioxidant in mayonnaise: Effects on physical stability, texture and sensory attributes. Food Science and Human Wellness, 5(4), 191-198. https://doi.org/10.1016/j.fshw.2016.10.002

25. Ranawana, V., Campbell, F., Bestwick, C., Nicol, P., Milne, L., Duthie, G., Raikos, V. (2016). Breads fortified with freeze-dried vegetables: quality and nutritional attributes: Part II: Breads not containing oil as an ingredient. Foods, 5(4), art. no. 62. https://doi.org/10.3390/foods5030062

26. Ravichandran, K., Ahmed, A.R., Knorr, D., Smetanka, I. (2012). The effect of different processing methods on phenolic acid content and antioxidant activity of red beet. Food Research International, 48(1), 16-20.

https://doi.org/10.1016/j.foodres.2012.01.011

27. Ravichandran, K., Saw, N.M.M.T., Mohdaly, A.A.A., Gabr, A.M.M., Kastell, A., Riedel, H., Cai, Z., Knorr, D., Smetanka, I. (2013). Impact of processing of red beet on betalain content and antioxidant activity. Food Research International, 50(2), 670-675. https://doi.org/10.1016/j.foodres.2011.07.002

28. Sawicki, T., Bączek, N., Wiczkowski, W. (2016). Betalain profile, content and antioxidant capacity of red beetroot dependent on the genotype and root part. Journal of Functional Foods, 27, 249-261.

https://doi.org/10.1016/j.jff.2016.09.004

29. Sawicki, T., Wiczkowski, W. (2018). The effects of boiling and fermentation on betalain profiles and antioxidant capacities of red beetroot products. Food Chemistry, 259, 292-303. https://doi.org/10.1016/j.foodchem.2018.03.143

30. Şengül, M., Yildiz, H., Kavaz, A. (2014). The effect of cooking on total polyphenolic content and antioxidant activity of selected vegetables. International Journal of Food Properties, 17(3), 481-490.

\section{https://doi.org/10.1080/10942912.2011.619292}

31. Slatnar, A., Stampar, F., Vebaric, R., Jakopic, J. (2015). HPLC-MS ${ }^{\mathrm{n}}$ identification of betalains profile of different beetroot (Beta vulgaris L. ssp. vulgaris) parts and cultivars. Journal of Food Science, 80(9), C1952-C1958.

https://doi.org/10.1111/1750-3841.12977

32. Sorour, H., El-Mesery, H. (2014). Effect of microwave and infrared radiation on drying of onion slices. International Journal of Applied Engineering Research, 2, 119-130.

33. Sucu, C., Turp, G.Y., (2018). The investigation of the use of beetroot powder in Turkish fermented beef sausage (sucuk) as nitrite alternative. Meat Science, 140, 158-166.

https://doi.org/10.1016/j.meatsci.2018.03.012

34. Šulc, M., Lachman, J., Hamouz, K., Orsák, M., Dvořák, P., Horáčková, V. (2007). Selection and evaluation of methods for determination of antioxidant activity of purple- and red-fleshed potato varieties. Chemické Listy, 101, 584-591.

35. Szopińska, A.A., Gaweda, M. (2013). Comparison of yield and quality of red beet roots cultivated using conventional, integrated and organic method. Journal of Horticultural Research, $21(1), 107-114$.

https://doi.org/10.2478/johr-2013-0015

36. Vasconcellos, J., Conte-Junior, C., Silva, D., Pierucci, A.P., Paschoalin, V., Alvares, T.S. (2016). Comparison of total antioxidant potential, and total phenolic, nitrate, sugar, and organic acid contents in beetroot juice, chips, powder and cooked beetroot. Food Science and Biotechnology, 25(1), 79-84. https://doi.org/10.1007/s10068-016-0011-0

37. Velíšek, J. (2014). The Chemistry of Food, 1st Edition, John Wiley \& Sons, Chichester, West Soussex, United Kingdom, p. 1124.

38. Wen, T.N., Prasad, K.N., Yang, B., Ismail, A. (2010). Bioactive substance contents and antioxidant capacity of raw and blanched vegetables. Innovative Food Science \& Emerging Technologies, $11(3), 464-469$.

\section{https://doi.org/10.1016/j.ifset.2010.02.001}

39. Wruss, J., Waldenberger, G., Huemer, S., Uygun, P., Lanzerstorfer, P., Müller, U., Höglinger, O., Weghuber, J. (2015). Compositional characteristics of commercial beetroot products and beetroot juice prepared from seven beetroot varieties grown in Upper Austria. Journal of Food Composition and Analysis, 42, 46-55. https://doi.org/10.1016/j.jfca.2015.03.005

Submitted: 1 July 2020. Revised: 10 September and 15 October 2020. Accepted: 19 October 2020. Published on-line: 9 December 2020. 